\title{
3 \\ Blasphemy accusations: Power, purity and the enemy within
}

During my fieldwork, I studied more than 50 incidents of blasphemy accusations closely and surveyed many others from a distance. One striking commonality between almost all the cases I came across was that they started within microlevel interpersonal relationships between people known to each other. While wider religious and nationalistic narratives that enable blasphemy accusations and punishments to take place are constructed and promulgated at structural and societal levels, it is within everyday interpersonal relationships that these narratives are acted outrelationships characterised by prior familiarity and hierarchical power relations, built on symbolic and conceptual boundaries. I focus on the everyday and the interpersonal to answer two interrelated questions: 1) what triggers blasphemy accusations; and 2) why are certain people targeted with these accusations? The discussion will show that accusations of blasphemy are often triggered by perceived transgressions of hierarchical symbolic boundaries and are made against expendable familiar others.

Most studies of blasphemy in Pakistan have argued that blasphemy accusations are usually a result of personal rivalries, and that blasphemy laws are used instrumentally ('abused' or 'misused') to settle personal scores (see, for example, Dobras 2009; Hoffman 2014; Khan 2015; Siddique and Hayat 2008; Uddin 2011). I argued in the Introduction against the law-centric understanding of blasphemy accusations and subsequent chapters will further elaborate on that. In this chapter, I want to expand the understanding of the motivations behind blasphemy accusations regardless of whether or not they are referred to authorities. While a substantial number of blasphemy accusations do indeed arise from 
personal rivalries and grievances between people—as the instrumental use' thesis posits - this explanation is too simplistic and does not take into account other contributing factors. I found a complex combination of motivational factors at play in most instances of blasphemy accusationsincluding personal piety, a desire for power and the purification of society, as well as local cultural and moral frameworks.

The purely instrumentalist explanations are often defensive and given in response to arguments describing blasphemy accusations as rooted in the religious beliefs and passions of Muslims. In my research, I found that, in most cases, it is impossible to distinguish between and neatly categorise the motivations as either instrumentalist or rooted in religious piety. Instead, more often than not, the accuser is both a vengeful person and a becoming Muslim - to use Naveeda Khan's (2012) term. The vengeful person is driven by a violation that may not be religious in nature but is still considered a transgression of social hierarchies or norms. The violation may be an aberration of character with respect to expectations, nonconformity with expected roles and behaviour or a transgression of the established social hierarchy. The becoming Muslim is motivated by a sense of guilt and sin and is living in a state of moral torment, constantly striving to be a good Muslim, the benchmark for which is set by the modern nation-state of Pakistan and the dominant religious rhetoric and continues to be raised higher. I argue that most accusations are driven by elements of both vengeance and personal piety at the same time.

\section{The transgression: Purity and social hierarchy}

The concern for purity is central to understanding how certain transgressions lead to blasphemy accusations in Pakistan. To understand the transgression as an impurity that needs to be removed, it is helpful to see it as a violation of conceptual categories and symbolic boundaries. Conceptual categories are preconceived notions of the right order of things in society-also described as a 'mental map'-the alteration of which is considered a violation (Krohn-Hansen 1994: 372). Symbolic boundaries are 'group-making social processes' that consist of meaningful classifications, cultural patterns and social practices that allow social actors to perceive a symbolic order of reality concerning their group identity (Hartmann 2015: 166-69). The violation of conceptual categories and 
symbolic boundaries can lead to physical violence in society (Hartmann 2015). It is this dual nature of violence with which I am concerned. Bowman (2001: 25) explains the etymology of the word 'violence', which is derived from 'violate', implying an 'integral space broken into and, through that breaking, desecrated'. Thus, Bowman (2001: 25) argues, in its passive grammatical sense, 'violate' indicates something 'characterized by impurity or defilement'. From this perspective, the transgression of social hierarchies and moral codes of conduct constitutes the primary instance of violence. Corbin (1976: 108) employed Douglas's (1966) concept of 'dirt' as 'matter out of place' to make a similar point about violence as a disturbance in the normal order of thoughts and ideological categories. The violation of conceptual categories of purity can lead to physical violence against those deemed transgressive.

Anthropological studies of violence have shown that discourses about purity/impurity are frequently invoked in violent conflicts and genocides around the world. Purity discourses were conjured in some of the most violent moments in recent history, such as the Holocaust (Hinton 1998), the Khmer Rouge genocide in Cambodia (Hinton 2005), the Hutu-Tutsi conflict in Rwanda (Malkki 1995) and Hindu-Sikh violence in India (Das 1996). However, while notions of 'pure' and 'impure' are employed in a wide range of violent contexts, 'the meaning of such conceptual categories' always takes on 'distinct local forms' (Hinton 2002: 19). The Holocaust, for example, drew on ideas of race and genetics, blood, soil, bodily aesthetics, and so on, to construct ideals of purity, whereas the Khmer Rouge employed agrarian metaphors and Buddhist notions of purity and impurity (Hinton 2002). Hinton thus argued that the broad conceptual categories of us/them and purity/impurity draw on local cultural patterns and refer to ideas that already have some symbolic value for the specific group of people.

Other scholars have argued that the cultural patterns and local forms on which the purity discourses draw should not be seen as given or fixed in time. Duschinsky (2013) argued that the categories of 'pure' and 'impure' are discursively constructed within specific sociopolitical circumstances. Appadurai (1998: 231) also argued, while acknowledging the importance of Douglas's ideas about 'purity and category-mixture' in understanding violence, that the categories of pure and impure are not 'culturally given'. Instead, in his explanation of ethnic violence, he demonstrated how notions of purity and impurity are contingent on subjectivities constructed within specific contexts (Appadurai 1998). 
According to Appadurai (1998: 236), 'purity is a matter of moral coherence'; a lack of moral coherence leads to moral anxiety, and deviant acts and thoughts can be perceived as transgressions. I have demonstrated in earlier chapters how the present moral anxieties of Pakistani Muslims are a consequence of specific historical and political circumstances. At the microlevel, ideas of purity and impurity are contingent on Pakistan's social hierarchies and the sensibilities of those in power when it comes to blasphemy accusations. Bail (2008: 39) argued that it is important to pay attention to how symbolic boundaries or notions of purity and impurity are often chosen, 'policed or made permeable' depending on the 'interests of majority groups'. In the light of this conceptualisation, I argue, blasphemy accusations are triggered by transgressions that disrupt the symbolic boundaries and moral coherence of the majority groups and those who are in power. Transgressions are perceived subjectively depending on the relationship between the accused and the accuser. The power structures within these relationships determine who is perceived as a transgressor and which 'cognitive, affective and cultural resources' are mobilised against them (Hartmann 2015: 166). The aim is often to punish the transgression of social hierarchies — perceived as an impurityto reassert the moral order of the society.

The underlying ideals of purity and impurity that define a transgression also vary depending on the respective places of the accused and the accuser(s) in society. For example, the religious identity of the accused is an important factor that determines the perception of purity and the transgressions thereof. To demonstrate this, I will use a variety of examples: the first case is an accusation against a Muslim woman, the next two cases are against Christians and the last case is an accusation against an Ahmadi. The narratives of purity invoked are different in each case; however, there are certain underlying themes that run through most of the narratives of purity presented here. The most significant of these common themes is the gendered understanding of purity. The transgressions are often conceived in terms of the sexual purity of women, even when the immediate violation is not at all sexual and the accused is a man. In the following examples, we shall see in further detail how narratives of purity are tied to women and their moral character.

The first case is of a Muslim woman, Marium, who was accused of blasphemy. She lived in a small, overcrowded mohalla ('neighbourhood') with narrow streets on the periphery of Lahore. She was the principal of a small school in the locality and offered religious sermons to the 
women of the area in her free time. She conducted these meetings at her house, where she preached religious teachings and also sometimes shared her own writings. She was accused of blasphemy for her allegedly deviant views, such as saying that 'singing the praise of the Prophet was not allowed' and the 'Prophet was simply another human being'. It must be noted that these views are already held by some groups and subsects within Sunni Islam in Pakistan. Marium, however, not only presented her 'deviant' views, but also challenged the existing hierarchical structure of the society. In her sermons and writings, she not only questioned mainstream interpretations but also asserted her own right as a woman to interpret and preach religion. It was the imam of the local mosque who officially accused her of blasphemy. The key witness presented against her was another religious cleric who used to teach the Quran to Marium's children. I met both of them (the accuser and the primary witness) several times and attended some of their court appearances as well. The imam who became the complainant against Marium told me:

She came to me one day with a copy of Quran and asked me to read certain verses from it. I told her that I had already read those and asked her what she wanted to say. She said that the 'Quran itself has walked to you'. I asked, 'How can the Quran walk to me?' She said that she is Syed, belonging to the Quraish bloodline [the Prophet's lineage] and has received revelations from God. I rebuked her by saying that she was telling a lie and that she should go away.

When I asked the imam whether it was then he accused her of blasphemy, he surprisingly said, 'No'. He explained to me that the women of the locality (including his wife) who used to attend the religious sermons at Marium's house had been telling their menfolk (including himself) about Marium's deviant (according to him) interpretations of religion for some time. He admitted that, despite the fact he had heard of the 'blasphemy' originally through women, no action could be taken against Marium because 'the women can't become complainants and witnesses in the court; it would require them to visit court every week and that would not be suitable for them'. Besides, men are the ones who are expected to be the protectors of religion and in effect the eligible claimants of spiritual purity. He also acknowledged the delay between the occurrence of the offences - which, according to him, continued for weeks-and the invocation of legal authority against the accused. Moreover, before the legal action was initiated, violent crowds besieged Marium's house, roused 
by some pamphlets containing 'deviant' interpretations of religion that she had allegedly published and distributed. It was under pressure from the violent crowd that police eventually arrested Marium and initiated formal proceedings against her. The imam claimed that it was he who had urged the police to intervene, 'otherwise there would have been destruction and bloodshed'.

Having talked to the accuser and other witnesses and followed the case closely, I am of the opinion that the story about Marium visiting the imam and sharing 'blasphemous' words, as alleged, was fabricated after the fact. In my view, there were two reasons behind this: first, to enhance the legitimacy of the blasphemy accusation, and second, to boost the religious authority and personal piety of the imam-in his own eyes as well as in the eyes of the public. The second point is demonstrated when he himself said:

The complainants generally stop appearing for trials because it requires a lot of commitment and religious passion to visit the court every week. Therefore, I myself became the complainant, as I did in another case that is also undergoing trial at the moment, to ensure that it is seen through to the end. Pursuing these cases provides me with a holy purpose in my life.

His religious authority in the eyes of others also increased, as one of his friends who had become closer to him after this case told me:

It is because of people like him that our society is surviving in the face of such atrocious sins [as blasphemy]. These people are like an embankment protecting the society from the flood of sins. It is due to these holy men holding up the society that, despite the tremendous increase in grave sins such as blasphemy in the present day, the Muslim community is still intact.

While the narrative of protecting society from 'impurity' caused by a 'flood' of blasphemy provides legitimacy to the role and authority of religious clerics, it also reinforces the idea of the presence of impurity and evil in society and the constant need to purge it. One of the lawyers who took up the imam's case against Marium in court reflected on the state of 'sin' (blasphemy) in society:

Too many cases of blasphemy these days-what a shame! This is such an unfortunate time to be alive when so many people are committing blasphemy every other day. We should not even be alive. We should die from shame for having seen so many cases 
of blasphemy in our lives. I feel more pain for these cases than even for murder cases. There was a time when a murder used to shake everyone, but nowadays so many people are dying every day in brutal circumstances that we have become desensitised to the cruelty of murder. However, we cannot get desensitised to the issue of honour of the Prophet. Blasphemy will always remain the most heinous crime in society.

Hence, in Marium's case, we see as the motivational factors behind the accusation both the strategic instrumental use of the blasphemy laws to punish the perceived transgression of a woman challenging the imam's authority by providing alternative religious interpretations and an aspiration for personal piety by removing 'sins' and 'impurity' from society. Purity in this instance is the purity of the correct religious beliefs and of religious authority according to the accuser and his supporters. Alternative interpretations of religion are a norm among lay people in Pakistan, as discussed earlier. However, Marium was a woman and her claim to religious authority represented a challenge and hence an impurity for the existing hierarchy. By punishing her transgression, the imam reasserted the ideal moral order of society according to him, and also established the purity of his own self. This is how blasphemy accusations grant social legitimacy to the accusers' endeavour to punish perceived transgressions, whether they are of social, moral or religious codes of conduct or the established hierarchy. Blasphemy accusations, hence, hold dual symbolic power: the power to legitimise violent action against one's rivals or those considered transgressive, and the power to grant social legitimacy, moral authority and a licence of spiritual purity to the accusers.

The second case is that of Sara, a young Christian woman from a poor family. It had rained heavily all morning one hot and humid day in the early monsoon when I met Sara and her family. I travelled by car to her small town, some 200 kilometres from Lahore. Sara's brother came to a mutually agreed landmark in the town to receive me so that he could direct me to their home. He was riding his Honda CD70 motorbike and told me that I would have to leave the car at a certain point beyond which the streets were too narrow for any vehicle except bicycles or slim motorbikes to get through. He led the way to a market area close to his neighbourhood where my car could be parked. We then entered a convoluted area of extremely narrow streets; I gave up after a few turns trying to memorise the route to be able to find my way back. The streets were paved but had open sewerage pipes running along both sides. The rain had made the 
mud and garbage mixture on the streets slippery. Despite that, there were tens of children of all ages, some barefooted, and a few little ones even bare-bottomed, playing on the streets. They all stared as we passed-Sara's brother on his bike, at a speed less than $5 \mathrm{~km} / \mathrm{h}$, and me walking carefully behind him to avoid slipping off the slimy path. We passed a mosque and a church — within a few hundred metres of each other-as we made our way to Sara's house.

The neighbourhood was inhabited by both Christian and Muslim working-class families. While there was some spatial segregation, as some of the streets were occupied by Christians or Muslims only, the residents interacted with each other regardless of their faith. There were certain limitations to those interactions, as in other parts of Pakistan-for example, Muslims do not eat at Christians' homes and there is no intermarriage. Everyday interactions include trade, the provision of services and even attending weddings and funerals of people from the other community. Rubi, a middle-aged Muslim woman who lived a few metres from the neighbourhood mosque and had good relations with the local imam's family (who lived next to the mosque), used to sew clothes for women in the neighbourhood. Sara's Christian family had been her customers for several years. Rubi was the one who accused Sara of blasphemy, when on her visit to Sara's house she saw some political banners with the names and pictures of politicians spread on the floor. She accused Sara of having insulted the Islamic names (of the politicians) and their beards (a symbol associated with the Prophet) printed on the banners by using them as floor mats. Rubi reported this to the imam of the mosque, who gathered a crowd of men and boys from the village and incited them to attack Sara and her family.

Sara's family had been living in that neighbourhood for 35 years. Rubi and her family, the imam and a majority of those who gathered to set Sara and her family on fire had also been living in the same neighbourhood for decades. The two families interacted with each other regularly, but their relations and interactions were the very basis of conflict. Rubi's sister-inlaw had eloped with one of Sara's cousins. While they had both returned to the community and denied the elopement, no-one in the neighbourhood believed them. Regardless of whether it was merely a rumour or the truth, there were several perceived transgressions within that scandal: a Muslim woman eloped, the man she eloped with was a Christian and they returned to the community without acknowledging any guilt or responsibility. 
The first retribution was against the man who had dared to commit such a transgression. All I heard from different people was that 'he could not stay in the neighbourhood anymore'. No-one said what would have been the consequence of him coming back to stay in the neighbourhood, but as has happened in other similar cases, he could have been killed by the woman's family. However, the transgression did not stop there, as the man stealthily returned to the neighbourhood for his father's funeral and stayed with Sara's family. Since it is hard to keep secrets in such a closely linked community, some people in the neighbourhood found out about this visit. This rumour upset Rubi's family and created friction with Sara's family. Rubi made the blasphemy allegations against Sara soon after this. Hence, in this case, while the violation was not essentially religious in nature, it was transgressive enough, and was seen as polluting and corrupting-an effect that had to be undone by active reinforcement of purity.

Similarly, in another case, Nadir, a Christian man, had an affair with a Muslim woman in his village. His brother told me that their relationship had been going on for about 15 years and was a constant concern for the village. The imam of the village's mosque, along with other Muslims, tried to convert Nadir to Islam a few times. They asked him several times to convert and marry the Muslim woman, to which he did not accede. The imam tried implicating him in false police cases related to the sale of alcohol, but he managed to evade the charges. Eventually, when he would not concede to any offence, he was accused of blasphemy by his Muslim friend Aslam. People from their village told me that Nadir and Aslam had known each other for years and were often seen together. Aslam accused Nadir of sending blasphemous text messages to his phone. They had been hanging out together even the night before the accusation. In this instance, the whole case may be a conspiracy against Nadir, triggered by the perceived transgression on Nadir's part and his defiance of all disciplining methods employed by the community. He was thus perceived not simply as an impurity himself, but also as an ongoing threat and danger to the purity of the society.

Sara's and Nadir's religious identity as Christians is key to understanding the perceived transgressions in both cases. In cases of accusations made against Christians, I suggest that the physical impurity embedded in South Asian understandings of caste is central to the perception of transgressions. I have written elsewhere about perceptions of local Christians as being filthy_polluted as well as polluting — bodies, and the physical and spatial segregation between Muslims and Christians in Pakistan (Ashraf 2018: 59). 
Most Christians in Pakistan belong to lower socioeconomic strata and are relegated to menial, 'dirty' jobs: cleaning toilets, removing animal dung, collecting garbage and so on. The physical segregation of Muslims and Christians ranges from the existence of specific Christian 'colonies' in the residential landscape to the use of separate utensils and crockery for eating and drinking. The treatment of non-Muslims as a 'threat to the health and purity of Muslims' has been documented in premodern Muslim societies as well (Emon 2012: 133). For example, non-Muslims were required to distinguish themselves from Muslims when attending communal baths so that they could not 'pollute the water unbeknownst to the Muslims therein' (Emon 2012: 133).

In present-day Pakistan, however, Christians are considered more polluting than other non-Muslim minorities such as Sikhs. They are treated with exceptional disgust due to a combination of factors, including their usually darker skin colour and their lower socioeconomic status compared with other religious minorities. The treatment of Christians as 'untouchables' can also be attributed to the persistence of 'caste ideology' with its inherent ideas of bodily purity and impurity (Fuller 1976: 68). Christians in Pakistan are believed to have converted from lower castes of Hindus, and continuing discrimination against similar groups of converts has been documented as the residue of the Hindu caste system (Dumont 1980: 203; Mosse 1996). While Pakistan's Christians are a religious minority, they are also categorised as a caste group in official documents. In fact, the police reports and court documents that I studied identified 'Christianity' as a zaat ('caste') rather than a religion. Thus, Christians are considered dually inferior in the social hierarchy, as a religious minority and as a lower-caste group.

Christians can thus transgress the social hierarchies and moral codes of conduct in both these domains: religion and the caste-based social hierarchy. ${ }^{1}$ In practice, however, the boundaries between religion and caste are not fixed and thus physical transgressions in the non-religious domain can also be framed as religious transgressions and punished accordingly. In the cases of Sara and Nadir, for example, the transgressions

1 I have discussed other examples of blasphemy accusations against Christians based on caste-based ideals of purity elsewhere (Ashraf 2018). Such examples include accusations following a Christian woman drinking from a Muslim woman's cup, Christians spreading decorative sheets featuring Quranic verses on one of their saint's graves and a Christian woman returning the 'polluted' butter she had bought from a Muslim woman. I came across many other examples during my fieldwork in which improper physical contact with Christians led to accusations of blasphemy. 
were physical and sexual in nature-even though Sara was substituted for the initial transgressor. Therefore, under threat were not only the ideals of purity based on social hierarchy and caste ideology but also the ideals of sexual purity, which are associated with honour. Das (1996: 62) argued in the context of Indian Punjab that 'two values, purity and pollution on the one hand, and honour and shame on the other, are particularly important for the regulation of sexuality' in Punjabi society. Pakistani Punjab shares the same cultural values: purity and pollution, honour and shame. Physical transgressions of the social and sexual boundaries are thus extremely offensive in themselves and the religious identity of Sara and Nadir as Christians added to that intensity. Hence, the accusations of blasphemy against Sara (in the absence of the man who was the real transgressor) and Nadir were a symbolic response to perceived acts of transgression of the social hierarchy, of the ideals of sexual purity and of religious boundaries_all at the same time.

In the case of Christians, therefore, caste ideology becomes a distinct factor in determining purity, impurity and transgression in social interactions. However, the types of transgressions seen as blasphemous are considered a form of impurity even in relation to Muslims. Interestingly, the ideals of sexual purity are invoked to prove the impurity of the accused even when the accused is a Muslim. A common belief repeated to me by supporters of blasphemy-related violence, from laymen to clerics and lawyers, was that whoever commits blasphemy does so because they are literally bastards; it had been forewarned by the Prophet himself that anyone who commits blasphemy would reveal his questionable ancestry'.

One of these people said to me with unshakeable conviction:

You can use modern science to determine the truth of the Prophet's saying. Go and test the DNA of any of the blasphemers and you will find that they were illegitimate children, impure by birth.

By calling blasphemers 'illegitimate children', the accusers are questioning the moral character-linked to sexual purity — of their mothers rather than the moral character of their fathers. Thus, it is women whose character determines whether one is pure or impure. Das (2007: 112) remarked in the context of Sikh militant discourses in India that the concern with establishing "pure ancestry" with the accompanying doubts about illegitimacy and true paternity are male doubts'. She argued that such an imagining of purity revealed that the community being constructed was a 'masculine nation' (Das 2007: 113). The tendency to question the 
ancestry of alleged blasphemers demonstrates that the purity discourses invoked in accusations of blasphemy are also embedded within a masculine and patriarchal imagining of the nation. The fact that masculine ideals of sexual purity are conjured in relation to Christians, Muslims and other groups also suggests that patriarchal notions of purity are widely applicable to Pakistani society. In addition to questioning the ancestry of the accused, the accusers and their supporters often also highlight the 'sexual impurity' of the accused in terms of zina ('illegitimate sexual relations'). In a high-profile case of blasphemy by a woman, I was told by those who supported the death penalty for her that 'she was sleeping with her sister's husband' before she was accused of blasphemy.

While the use of sexually insulting words against those one disapproves of is common in most cultures around the world, the strong association between being blasphemous and being sexually impure-through deviant sexual conduct or by virtue of being born to a sexually impure motheris of curious concern here. The offence of blasphemy and the offence of sexual transgression (or sexual impurity) appear to reaffirm each other. One is likely to be accused of being a blasphemer when one transgresses norms of sexual conduct (violates women), and a blasphemer is deemed inherently sexually impure. It appears to be a circular argument where the offence itself is used as evidence of its commission. However, it is significant as it offers us insights into two important arenas of thought: the moral values that are central to the culture and the power of language. As far as moral values are concerned, I have already argued for the centrality of the value of purity in the lives of Pakistani Muslims, and more generally in South Asia. The emphasis on sexual purity is also a reflection of strongly patriarchal concerns for control over sexuality in both the South Asian and Islamic ideals to which South Asian Muslims ascribe. More important here, I argue, is the power of language as a 'social performative' through which social identities are called into being (Pennycook 2004: 14). The use of words is not merely to signify something, but also to do something. Hence, by asserting that a blasphemer is sexually impure, a socially sanctioned identity is called into being. The performative function of the language is thus 'the discursive constitution of the subject as inextricable from the social constitution of the subject' (Butler 1999: 120). The sanctions of sexual and religious impurity corroborate each other to construct the social identity of an alleged blasphemer. It can therefore be argued that moral sanctions are superimposed on one another to effectively and definitively dismiss what is perceived to be transgressive or impure in society. 
The final example I want to discuss is the case of an Ahmadi man named Rashid. He was in a relationship with a Muslim woman, Nida, whom he met at an after-school academy they both attended. They had been talking to each other for about two years and had developed feelings for each other. Rashid wanted to marry Nida and sent a marriage proposal to her family. Nida's mother was doubtful about whether Nida already knew Rashid, so she asked Nida to tell her everything about their relationship. It was then that Nida told her mother that Rashid was from an Ahmadi family but had 'converted to Islam in front of her'. Nida's mother was suspicious and told Nida not to trust Rashid because 'Ahmadis lie about being Muslims'. Nida did not have any doubts about Rashid's sincerity, so she was devastated to hear her mother's judgement. When Nida continued to insist on marrying Rashid, her mother took her to a religious scholar for an 'expert opinion' on the matter. The religious scholar, who was friends with one of the lawyers with whom I was meeting regularly for my research, invited the lawyer along to one of his meetings with the mother and the daughter. The lawyer, who supported punishment for blasphemy, invited me as well. Thus, I met Nida and her mother in the presence of the legal and religious experts on the matter.

Nida's mother told me how her daughter had been deceived and led astray by Rashid. She told me that she was very thankful to Allah that she found out the truth in time and brought Nida to meet the religious scholars, who told her 'the realities of the Ahmadis'. She claimed that her initiative and the religious guidance from the scholar had dissuaded Nida from 'following a crooked man to hell'. She claimed that her daughter was now much safer. Tears rolled down Nida's cheeks as she nodded and said:

It is hard for me. I believed in Rashid and had developed a strong emotional attachment with him. But I guess my mother is right. I guess it is all in my better interest. After all, I do not want my kids to be born in a false religion. Maybe it is all good for the purity of my own faith. But it is very hard to accept at this time. I have started praying regularly to deal with the trauma. Allah will help me. I will be better soon.

Later, there was a suggestion by someone in the room that Rashid had 'posed' as a Muslim, which is a crime (according to Pakistani law) and a serious transgression that should be punished. They contemplated how best to make Rashid pay for his crime. Everyone in the room tried to convince Nida to lodge a formal complaint against Rashid to ensure that he did not fool any other Muslims. I did not meet them again due to some 
unexpected developments in my fieldwork, so I do not know whether they followed through with the complaint. But what I witnessed was a blasphemy accusation in the making. In this case, the main concerns were the purity of the nation and the purity of their faith.

In the cases of accusations against Ahmadis, the theme of deception forms a key concern in perceptions of purity and transgression thereof. Appadurai (1998: 234) pointed out the 'tropes of deception, treachery, betrayal, imposture, and secrecy' that are sources of 'cognitive paranoia' about the identity of the enemy. He suggests that fear of deception, linked to uncertainty about the identity of the other, is inherently also linked to the desire to achieve and maintain the purity of society (Appadurai 1998: 236). Deception is thus an impurity that is considered an even more dangerous transgression by the very virtue of its indistinguishability from the pure. Therefore, Ahmadis, for most Pakistani Muslims, are transgressive by the very fact of their 'hidden' identity because they claim to be Muslims. The possibility of the corruption of society is thus seen as materialising in the very existence of the Ahmadis. Hence, the purity of the nation (based on the religious identity of Muslims) is at stake in instances of blasphemy accusations against Ahmadis.

Through different examples of blasphemy accusations in this section, I have highlighted various underlying ideals of purity — of religious belief, authority, caste, sexual behaviour, women, ancestry, nation and of the self-the transgression of which may trigger accusations of blasphemy. The cases have shown that, despite the frequent instrumental use of blasphemy accusations against one's rivals, the explanation for these accusations cannot be reduced to instrumentality. In most instances, the accusations are driven by personal vengeance as well as underlying concerns about the purity of conceptual categories. The notions of purity are based on social hierarchies and boundaries — not only of religious identity but also of caste and other systems of stratification. Depending on the context of the case, various ideals of purity and respective moral sanctions can be superimposed on to each other to effectively discipline the transgressors. The transgressions or violations committed by an individual are often seen as transgressions against the community and the moral order of the whole society. In many cases, those 'violated' (for example, Rubi's sisterin-law or Nadir's Muslim girlfriend) do not perceive the violation as such; rather, the defenders of society—imams or other men — are the ones who step in to determine the transgression and punish it. Thus, transgressions arise within interpersonal relationships but are then transformed into acts of communal and national shame. 


\section{The accused: Familiarity and the enemy within}

Prior familiarity between the accused and the accuser(s) is a common characteristic of most blasphemy accusations in Pakistan. The cases I have discussed so far involved people who already knew each other and had an ongoing interactional relationship. The accuser(s) and the accused can be neighbours, colleagues, linked through trade and/or exchange relationships and sometimes even friends. Violence among neighbours and familiars is not a unique or new phenomenon. Some of the most violent moments in the recent history of humanity have seen 'familiar' people turning against each other (for example, in Poland during the Holocaust ${ }^{2}$ and in Punjab and Bengal at the time of Partition of the Indian Subcontinent). Studies of witchcraft accusations in modern-day Indonesia have also highlighted the 'familiarity' of the accused as a significant factor contributing to the phenomenon. Herriman (2006: 363) writes about witchcraft being a primarily local phenomenon in which neighbours accuse each other and the whole village then violently purges the accused. Siegel, in his book Naming the Witch (2006: 188), argues that the uncanny other (the witch) emerges from the familiar. In his large-scale comparative study of communal violence in societies, Tambiah (1996: 276) contended that:

assailants and victims are frequently not strangers to one another. They have been 'neighbors' in the loose sense of having lived in the same towns, or resided intermixed or side by side.

Similarly, Appadurai (1998: 238) showed through various examples 'the transformation of neighbours and friends into monsters' as a common feature of ethnic violence. He argued that it was because of the 'uncertainty' and 'cognitive paranoia' associated with those others within the community that they were pinned down as 'the enemy within' (Appadurai 1998: 234).

Žižek, in his 'Neighbors and Other Monsters' (2006), also showed how neighbours and other familiar people occupy an ambivalent and uncertain place in society. He identified a spectrum of otherness that ranges from: 1) the other, as in 'other humans like me'; 2) the other as the symbolic 'Big

2 As Gross (2001) demonstrated in his groundbreaking study of Jedwabne, Poland. 
Other' ${ }^{3}$ - that is, the rules of our social coexistence; to 3) the 'Other qua Real', the 'impossible thing, the inhuman partner, the other with whom no symmetrical dialogue mediated by the Symbolic order is possible' (Žižek 2013: 143). He argued that in the image of the neighbour as 'the other like me' always lurks the other extreme: the unfathomable, monster, radical Other (Žižek 2013). Hence, the people who are known and familiar but occupy the position of the non-specific 'other' are the ones who can be transformed into the 'absolute other', against whom violence is then justified. It is the very quality of familiarity that implies some degree of 'sameness' due to which the enemy within must be forcibly expelled and objectified as 'the total other' (Tambiah 1996: 276). In so doing, the 'difference' with the enemy, or the transgressions that turn them into the enemy, must be exaggerated to an extent that the 'other' is 'degraded, dehumanized, and compulsively obliterated' (Tambiah 1996: 276).

In the case of blasphemy accusations in Pakistan, I argue that familiarity is significant because it informs the perceptions of the character of the accused in the minds of the accusers. These perceptions are not pieces of neutral or benign information; rather, they impact on the likelihood of being 'offended' by the words/actions of the person in question. They shape and impact on how a person's certain actions and behaviours are received and the reactions they generate. My broad survey of blasphemy cases-both officially registered and unofficial rumours leading to violence-reveals that blasphemy accusations overwhelmingly take place in physical and social spaces with identifiable characteristics. The physical space can be a neighbourhood, village, mosque, school, workplace or market. However, in most of the cases, these spaces are inhabited by people from lower socioeconomic strata, with highly cohesive social networks, unlike those in affluent urban areas. These are the areas where social policing of individuals and families is generally very high, whether it is the clothing choices made by one's neighbours or colleagues, the company one keeps, the food one eats or the social interactions in which one engages. There are indirect ways of controlling people's behaviour, such as gossip and reputation-based social relations, as well as direct ways such as accountability to local moral authorities (religious clerics, elder men of the community or other influential members) or the mob. Such

3 The symbolic 'Big Other' is 'the "substance" of our social existence, the impersonal set of rules that coordinate our coexistence' (Žižek 2013: 143). 
close monitoring of social behaviour sets these places apart from more affluent and urbanised areas where social policing (along with communal solidarity) has been in decline in recent decades.

Hence, in most cases of blasphemy accusations, people are generally familiar with one another's social identity, behaviour, family background and networks. This familiarity means that those with lesser power in social relations are more likely to be accused. The accusers make accusations when they know they can mobilise support against the person they are accusing. Moreover, familiarity means that the accusers know which parts of the accused's identity and behaviour can be marked as transgressive to mobilise support against them. The accusers in most incidents of blasphemy accusations are not only familiar with the names and faces of the accused beforehand, but also target major markers of their social identity (for example, Christian, Muslim, Shia, Ahmadi, liberal, secular, Deobandi, Sunni) and personal conduct. It is this information that determines what will be deemed offensive and transgressive. For example, in his iconic statement before the court after killing Salman Taseer, the Governor of Punjab, Mumtaz Qadri proclaimed:

The personal life of Salman Taseer shows that right from early times he proved himself as an infidel. He married three times. One of his wives was 'Sikh' by religion. He arranged his so-called marriage in a secret way with that lady in New Delhi in India. His lifestyle, faith and living with a lady of non-Muslim faith, reflecting his act of living in constant state of Zina ['adultery'] under the pretext of marriage [which is not permissible in Islam] speak volumes about his character and associated matters. ${ }^{4}$

While Qadri did not know Taseer on a personal level, he had been working as Taseer's bodyguard. Moreover, this is a rather exceptional case because Taseer was a public personality and his personal traits were well-known, as was his vocal stance against the blasphemy laws. In addition, he was seen to represent the lifestyle and political position of the Westernised elite-a whole subsection of Pakistani society. Thus, in this case, the general vilification of the alleged blasphemer's character becomes a magnified symbolic act. In many other cases, familiarity with the 'character' of the accused can determine whether the accusation even occurs. Asad and Zain, the accusers in another case of blasphemy against

4 Malik Muhammad Mumtaz Qadri vs The State (2015) Criminal Appeals No. 210 and 211 of 2015, Supreme Court Islamabad: 6. 
a Christian man with whom they used to work, told me that the accused was training to be a pastor. They asserted that he used to study the Bible and other religious texts of Christianity, and thus they merely expected he would insult one of the Islamic books (a publication by a local religious leader) that belonged to the accuser. In yet another case, a man who accused one of his neighbours, a Muslim woman, of blasphemy, said to me in an interview:

Have you looked at the way she dresses? She wears jeans and goes around with open hair and so much make-up on her face. Can you expect people like her to respect our religion? She was always unobservant of Islam and one day crossed the limits.

Thus, we see the familiarity of the accusers with the accused is of immense significance in determining the 'offence' or 'violation' that leads to an accusation of blasphemy. However, it is not just that familiarity that leads to blasphemy accusations; it is also a transgression through which the familiar others cross the prescribed limits of the given relationships. In other words, it is proximity and a delicate balance of intimacy in those relationships that may tip one from being a familiar other to the 'absolute Other' - the enemy who has crept in and, by so doing, transgressed the normal order of things.

The other is an existential issue for the one who, in constructing the other, identifies and legitimises the self. The others thus created are 'containers of one's disavowed aspects' (Kakar 1990: 137). The disavowed aspects are 'unacceptable, condemned parts of the self' that are 'projected outside' (Kakar 1990: 137). The other, in this sense, 'is a transgressor of deeplyheld taboos' (Kakar 1990: 138). In pointing out the other as the enemy, the self substitutes 'the enemy one harbors within oneself' (Tambiah 1996: 277). One's personal piety cannot be questioned if one accuses someone else of being impure. One's authority must be pure and legitimate if one calls those who question it impure. A similar argument is made by Siegel (2006) with regard to witchcraft accusations in Indonesia. He suggested that the fear that anyone-including one's own self_-could be a 'witch' is what drives people to find the 'witch' in others. He writes:

The witch is always a dual personality. One can say that the witch is the other of the self as it goes ordinarily unexpressed. Precisely for this reason, he is unacceptable. Witchcraft is the 'proof', when the possibility is pressing, that one cannot take the place of the other. 
That one is not oneself what one accuses the other to be; one is not him and one cannot find oneself in his place. Once the witch is expelled, the world works again as it should. (Siegel 2006: 203)

Thus, it is the possibility of the impurity of the self that leads to pointing out transgressors of symbolic boundaries and social hierarchies as others outside the self. While individuals accuse one another of blasphemy, driven by individual concerns for piety and purity, the figure of the blasphemer represents more than an individual. Even though accusations are made against specific individuals, those individuals symbolise something greater than themselves: the sin, the impure, the undesirable difference, the unacceptable change in society. The accused are thus chosen either from the margins of the society or from those who transgress the conceived boundaries within that society. They are familiar but not known, they are the ones who can be condemned and dismissed as killable bodies- 'bare life' - with the sanction and support of the community (Agamben 1998). As Siegel (2006: 137) suggested, the witch is, 'underneath his appearance as neighbour, the embodiment of a foreign force'. Blasphemers, similarly, are the face of the haunting evil and the impure in the individual and collective identities that are steeped in moral anxiety, as we saw earlier. It is the abstract speculative evil that is bigger than their individual experiences of evil and sin around them. Hence, blasphemy accusations can also be called an 'attempt to give the uncanny a face' (Siegel 2006: 147).

\section{Conclusion}

Blasphemy accusations in Pakistan take place within everyday interpersonal interactions between people already known to each other. The accusations are a manifestation of existing tensions and hierarchies within these relationships. They are triggered by perceived transgressions of symbolic boundaries and the moral order of society. The motivations behind such accusations are neither purely religious nor entirely instrumental in nature. They are embedded in local power structures and ideals of purity based on various religious and cultural moral frameworks. The accused are the expendable familiar others against whom power and support can be mobilised. Once accused, they become the face of the uncanny evil and $\sin$ in society. 
At a structural level, accusations of blasphemy are also a result of complicated, interconnected social, political and historical processes. In the previous chapters, I have highlighted the conception of the idea of Pakistan' as a qualitative change in the course of historical events that continues to impact how the self, the community and the other are understood and constructed in Pakistan. Moreover, the reformist movements within South Asian Islam, in response to British colonisation, shaped not only the movements for Pakistan, but also the public religiosity of Pakistani Muslims. While these movements began with various groups of elite Muslim scholars who were influenced by modernity's ideals of individual responsibility and who were aspiring to return to the assumed purity of an idealised bygone era, they have come to increasingly shape the religious sensibilities of ordinary Muslims in Pakistan. Nevertheless, despite the undeniable significance of the historical contingencies and the role of the state of Pakistan in enabling the issue of blasphemy to become a destructive force in society, the aim of this chapter has been to demonstrate how the larger religious and political trends are acted out by people at the local level.

Thus, notwithstanding the institutionalisation of the ideals of piety, purity and exclusivity by the state of Pakistan, and the popularisation of absolutist religious discourse, this chapter has shown 'the ways in which the conceptual boundaries of the state are extended and remade' in the everyday lives of its citizens (Das and Poole 2004: 20). However, as Das and Poole (2004: 22) warned, everyday lives or 'local worlds' do not stand in binary opposition to the state; rather, they are enmeshed with the state. I see this correlation in terms of what Foucault (1982: 785) called the 'political "double bind", which is the simultaneous individualization and totalization of modern power structures'. It means that the exclusivist tendencies driving the need for purification are simultaneously ingrained in individual lives and state structures; it is not simply a top-down application of power. Instead, ordinary people also have the power to shape what will then become the focal point for mobilisation to agents vying for power in the political sphere. My account of blasphemy accusations with an emphasis on the microlevel relationships between the accused and the accuser(s) demonstrates how the state is continually formed in the recesses of everyday life' (Das and Poole 2004: 23). It is not merely the conception of the idea of Pakistan as 'the land of the pure' that enables the use of blasphemy accusations as a mechanism of purification in society. The practice of the same at the local level also contests and continually redraws the metaphorical borders of 'the land of the pure'. 
This text is taken from Finding the Enemy Within: Blasphemy Accusations and Subsequent Violence in Pakistan, by Sana Ashraf, published 2021 by ANU Press, The Australian National University, Canberra, Australia.

doi.org/10.22459/FEW.2021.03 